\title{
THE WRITTEN FEDERAL ATTORNEY EXAMINATION
}

\author{
HENRY WEIHOFEN*
}

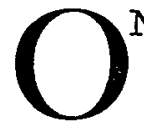

N SEPTEMBER 26, I942, more than 13,000 lawyers took the written examination for government legal positions conducted by the then Board of Legal Examiners, now the Legal Examining Section of the United States Civil Service Commission. This was probably the largest number ever to participate in a single law examination. The program for placing the government's attorneys under civil service, of which this examination was a part, has been discussed in other articles. ${ }^{x}$ The purpose of this article is to explain the nature of the written examination and the types of questions used. Another, similar examination will probably be offered in the near future, and so prospective candidates particularly may be interested in the nature and results of the past examination.

The written test was in itself only the first step in the examining process. Out of the total group those attaining the highest scores in each state-about 3,000 in all-were called for oral examination before state committees made up typically of a judge, a practicing lawyer, and a law professor. These committees further pruned down the group to less than 2,000, who were then placed on the list of those eligible for appointment. All legal positions in the federal government paying $\$ 3200$ per year or less (not including increases recently granted), with few exceptions, must now be filled from this list.

The examination was something of an experiment. The questions differed considerably both in form and in content from the usual law school or bar examination questions.

There were eighty legal questions, and four hours' time was allowed for answering these questions. In addition, the examination included eighty verbal questions, to be answered in one hour, and ninety questions on

* Chief, Directive Order Section, National War Labor Board, formerly principal attorney, Board of Legal Examiners.

I Wechsler, Lawyers under the United States Civil Service: the Work of the Board of Legal Examiners, 9 Am. Law School Rev. I307 (I942); Weihofen, Investigational Possibilities in the Area of Examination Techniques, 9 Am. Law School Rev. I329 (r942); Wechsler, A Federal Civil Service Program for Lawyers; the Work of the Board of Legal Examiners, I Lawyers Guild Rev. 5 (I94x); Reilly, Founding a Career System for Government Lawyers, I Lawyers Guild Rev. I (I94I). 
"general information," to be answered in one hour. A total of six hours was allowed for the entire examination.

The verbal questions consisted of definitions, reading comprehension items, and some questions in logic. The general information questions were mainly in such fields as economics, history, and government. The information required was fairly elementary and not likely to prove too difficult for any lawyer of average education abreast of current events and alive to the problems of government.

The legal questions represented an innovation, in that they were designed to test not specific legal information as such, but ability to think like a lawyer and to perform the analytical, deductive and interpretative functions involved in legal work.

In determining whether a lawyer is or is not eligible for appointment to a government legal position, our concern is about his skill in performing the various functions which such a position involves. The direct way to test such skill would be to find out how he conducts a trial, writes a brief, interprets a regulation, etc. But to have each of 13,000 applicants conduct a case before an examining board or do a research and briefing task under an examiner's eye is obviously impossible.

One method of procedure is the usual one of testing for legal knowledge, in the hope that the man who knows the law is likely to be a competent lawyer. But knowledge and skill are not synonymous: one may have a great deal of knowledge about swimming and yet not be able to swim. For the purposes of the attorney examination, such a knowledge test seemed particularly inept. In law school and bar examinations, knowledge may properly be considered of prime importance. Students who have just finished a course may properly be tested to determine how well they have learned what they have just been taught. Bar examinations may properly test for knowledge of specific rules or principles to determine whether students who have only recently studied those subjects have learned enough to be qualified to practice.

But the candidates who took this examination had for the most part finished law school and been admitted to practice. Most of them had been in practice for years. An examination in the content of specific law subjects, therefore, seemed, at best, unnecessary duplication, and at worst a wholly inappropriate method of testing the legal competence of practicing attorneys. There seems to be almost no legal subject of such universality that every lawyer may reasonably be expected to be well versed in it. The personal injury lawyer will very likely have forgotten even the rule in Shelley's Case, let alone springing uses and restraints on alienation; the 
lawyer in corporate practice may not remember the definition of a simple assault. Yet both may be highly competent men in their own fields and quite capable of doing the research necessary to handle any legal problem they may meet. Even the most general practitioner probably never touches upon more than a small part of the law and quickly forgets most of what he ever knew about the rest. The government's legal work ranges over so many different subjects that it can use competent men in any field; in most fields, especially in the lower positions, the government does not demand specialization but is willing to employ men of general competence and train them in the specialized work they are to do.

The Board of Legal Examiners therefore came to the conclusion that it should attempt to devise an examination which would test for general legal competence, without calling for specific knowledge of any given field of law. The questions were designed to test ability to apply precedents, to see the relevant point in a fact situation and to construe statutes. Examples below will illustrate the types of material used. Some of the most ingenious of the questions were suggested by law professors in the various schools. If the examination serves to uncover new possibilities in the use of objective type questions, the credit belongs less to the staft of the Board than to the thirty or forty law teachers whose contributions formed the basis of many of the questions asked.

All the questions were of the objective type, i.e., questions calling for no written answers, but requiring merely marking on an answer sheet which of several suggested answers was correct. This type of question has come into use in law schools to some extent, largely in its most rudimentary form-the so-called true-false question. While the true-false question is probably the best known, at least to law teachers, ${ }^{2}$ it is probably also the most abused form of objective question. As generally used, the truefalse question is confined to factual material, testing only ability to recognize from memory the correct one of two answers, and affording no opportunity to test for ability to think constructively. This is the one well known form of objective question not used on the federal attorney examination. The types used are explained and illustrated below.

Multiple choice form.-Considerable use was made of a fundamental objective test form which may be called the multiple choice or best answer form, in which for each question the examinee is required to make a choice among a number of possible answers (usually five). This form of objective

${ }^{2} \mathrm{~A}$ number of law teachers have recently been experimenting with more developed and intricate forms of objective questions. See, for example, the questions in contracts drafted by George W. Goble and Edward F. Potthoff of the University of Illinois. Potthoff, Examinations in Contract Law Courses, University of Illinois Bulletin, vol. 39, No. 35 (I942). 
question is perhaps the most easily adapted to many different fields. It may be used in very simple form, calling for mere recognition of items of information, as in questions $3-7$, ,o and 12 below, or in much more complex form, calling for difficult analysis of a mass of facts, application of principles, inference, meaning, etc. It may be used in reverse, calling for ability to pick the wrong or incorrect answer, as in examples 2 and I 2 below.

Even when the question does not in form ask the examinee to select the incorrect answer, it may test for knowledge of what is not correct as well as what is correct. In question Io below, it is probable that a majority of the examinees'were not acquainted with the name of Judah P. Benjamin. However, if a person recognized the names of the other four, he knew that none of them was a leader of the Confederacy, and so he could reach the correct answer by a process of elimination. Thus the question actually tests ability to discriminate among several choices on the basis of related information other than that directly called for.

A multiple choice question is capable of testing ability not merely to make black and white distinctions, but also to recognize the doubtful or borderline case, as in example $I_{7}$ below. A group of questions of this type may be given based on the same body of data. The legal parts of the examination contained several such groups in which a statute or regulation was quoted, and then a number of questions presented calling for comprehension and interpretation of this material. Examples will be found in questions $16-19$ and $20-27$, below.

\section{MULTIPLE CHOICE FORM}

A. VERBAL

r. "A great jurist has said that there is, save abstractly, no such thing as the 'reasonable and prudent' man. By virtue of the fact that we are all members of the human race, we have common characteristics; by virtue of the fact that we are individuals, we all display specific variations in specific human capacities. We may intellectually set up a norm or standard, but it will be a norm or standard from which every individual is bound to vary."

The quotation implies that the usefulness of a norm or standard for human conduct is restricted because $(A)$ we are all members of the human race $(B)$ specific variations in given traits are present between certain individuals (c) human beings have common characteristics (D) no one can be found who precisely fits the norm (E) individuals rarely have common characteristics and common specific capacities.

2. "Except where the transgression of constitutional liberty is too plain for argument, personal freedom is best maintained-so long as the remedial channels of the democratic process remain open and unobstructed-when it is ingrained in a people's habits and not enforced against popular policy by the coercion of adjudicated law." 
The quotation does NoT imply that $(A)$ respect for the Constitution is generally ingrained in public policy $(B)$ generally, the best way to maintain personal liberty is to have it rooted in the habits of the people (c) democratic processes sometimes provide a means of insuring personal freedom (D) popular policy may be opposed to personal liberty $(E)$ the law may sometimes enforce the maintenance of personal freedom.

For each of the words in capitals listed below, indicate on the answer sheet which one of the five suggested words which follow it has most nearly the same meaning.

(D)

3. VoLUBLE excitable

4. PERfunctory

5. ACUMEN officious

6. SAIUTARY

7. EMOLUMENT experience initial benefit

$\begin{array}{lll}\text { annoying } & \text { garrulous } & \text { insolent } \\ \text { petulant } & \text { hazardous } & \text { careless } \\ \text { confidence } & \text { efficiency } & \text { discernment } \\ \text { beneficial } & \text { crucial } & \text { apt } \\ \text { obligation } & \text { option } & \text { bribe }\end{array}$
persuasive deplorable toleration sedative memorial

\section{B. GENERAL IMPOBKA TON}

8. The CHIEF reason for providing for a bicameral, rather than a unicameral, legislative body in the Federal Constitution was to (A) attain the execution of the will of the majority of the voters (B) effect a method that would compromise the conflicting demands with respect to the basis of representation (C) provide adequate representation to urban areas (D) permit the division of the legislative burden ( $E$ ) prevent gerrymandering.

9. Of the following sources of individual income, the one that is usually subject to the IEAST variation in amount from year to year is $(A)$ earnings from the sale of farm products (B) dividends from common stock (C) wages from factory labor (D) returns from investments in bonds $(E)$ real estate rents.

Io. Of the following men, the one who was an active leader of the Confederate States during the Civil War was (A) Stephen Douglas (B) Edwin M. Stanton (C) Judah P. Benjamin (D) William H. Seward (E) John C. Calhoun.

II. Of the following alleged justifications for imprisonment for criminal acts the one LEAST COMMONLY accepted by modern jurists is that the purpose of imprisonment is to (A) exact vengeance for injuries to society (B) promote the rehabilitation of criminals (C) deter the general population from committing crimes (D) isolate the criminal from situations in which he can commit crimes (E) discourage criminals from the commission of future crimes.

I2. Of the following topics, the one that has Nor been the subject of major Federal legislation during the last ro years is $(A)$ sickness and health insurance (B) stock market regulation (C) reciprocal trade agreements (D) minimum wages and hours in industry ( $\mathrm{E}$ ) unemployment insurance.

\section{LEGAX}

I3. Ames, through his agent, Hand, made a contract with Bent for the purchase of 200 gallons of liquor. It was specifically agreed that the liquor was to be delivered on or before March I5 , because Ames wished to avoid paying the higher tax which would be 
imposed on such sales after that date. The truck delivering the liquor arrived after business hours on March 15 . The truck driver, Otis, carelessly backed the truck into Ames' loading platform, damaging it, and Ames now sues Bent for the damages so sustained. In this action, which of the following facts is most clearly relevant? (A) Ames intended to avoid payment of higher taxes (B) delivery had not been made as specified (C) Bent knew that Hand was acting as Ames' agent (D) Otis was acting as Bent's employee (E) delivery by truck was the usual and reasonable means of delivering such goods and was the means contemplated by the parties.

I4. The director of a Federal penitentiary located in the State of $X$ is charged with violating a State law requiring the display of a sign, "Oleomargarine is used here," in all public restaurants and dining rooms where oleo is used. Oleo is served in the mess hall of the prison. To determine whether the director can be punished under this law, which one of the following cases is most probably decisive? The State supreme court had decided that the act $(A)$ does not apply to private homes not serving meals for gain (B) does not apply to a cafeteria for employees operated in the Post Office building (C) does apply to county jails (D) does apply to boarding houses (E) does apply to railroad diners.

I5. Ned, aged $x_{5}$, sees an automobile belonging to a neighbor, Yoe, on the street with the keys in the ignition, and decides to take it for a "joy ride." He intends to return it in an hour or so, but while driving at $6_{5}$ miles per hour, Ned wrecks the car. The car is insured against fire and theft. In a suit by Yoe against the insurance company, the most relevant fact is that $(A)$ Ned is a minor (B) he was driving in excess of the speed limit (C) he intended to return the car (D) no other person but Ned was involved in the wreck (E) Ned did not intend to wreck the car.

\section{QUESTIONS 16-19}

An Act of Congress of I 900 provided with regard to the Island of Puerto Rico:

" ... . No corporation shall be authorized to conduct the business of buying and selling real estate or be permitted to hold or own real estate except such as may be reasonably necessary to enable it to carry out the purposes for which it was created, and every corporation hereafter authorized to engage in agriculture shall by its charter be restricted to the ownership and control of not to exceed five hundred acres of land; and this provision shall be held to prevent any member of a corporation engaged in agriculture from being in any wise interested in any other corporation engaged in agriculture. Corporations, however, may loan funds upon real estate security, and purchase real estate when necessary for the collection of loans, but they shall dispose of real estate so obtained within five years after receiving the title. Corporations not organized in Puerto Rico, and doing business therein, shall be bound by the provisions of this section so far as they are applicable."

16. The firm of Green and McKnight, a partnership, wishes to operate a real estate business in Puerto Rico. Which ONE of the following statements best describes what the firm may legally do under the above Act? The firm may (A) act as agent, on commission, for persons desiring to buy or sell real estate (B) loan its own money on mortgage securities (c) do both of the above (D) buy and sell real estate itself for speculation (E) do all three of the above. 
17. The Allied Fisheries Company, Incorporated, does a fisheries business in Puerto Rico. Some of the following activities of the company are clearly legal under the statute; others clearly illegal. Which ONE is MOST DOUBTFUL, in the sense that it is neither clearly legal nor clearly illegal? (A) Buying a 5-story office building, one floor to be occupied by the firm itself, the rest to be rented out (B) buying and selling real estate for itself, for speculation (C) investing some of its money in 40-year real estate mortgage bonds (D) purchasing at a foreclosure sale, for less than the amount of the bonds, real estate secured by mortgage bonds held by it (E) buying shares of stock in a corporation operating sugar plantations in Puerto Rico; it owns no stock in any other corporation.

I8. The Tecla Minning Company, a corporation owning 400 acres of mining land in Puerto Rico, wishes to acquire an additional tract of 300 acres which is now devoted to farming, but which the company believes has mining value and wishes to use for mining. Which one of the following describes the choice or choices legally open to the company under the statute? It may $(A)$ take a mining lease on such tract, giving it the right to mine the land but reserving surface rights to the present owner $(B)$ take such a lease on 100 acres of the tract (c) do either of the above (D) trade roo acres of minerally exhausted land for the mining rights in the new tract $(E)$ do any of the three things mentioned above.

I9. Mr. Barnes, a lawyer, is the owner of to shares of common stock of the Porico Sugar Company. Which of the following most completely states what Barnes may legally do? (A) Accept a position as general counsel of the Tecla Minning Company (B) accept a position as vice president of the Porico Sugar Company (C) either or both of the above (D) accept a position as vice president of the Southern Sugar Company, a corporation which also operates plantations in Puerto Rico $(E)$ any or all of the above.

\section{QUESTIONS 20-27}

Read the following material describing or quoting Executive Orders and statutes and then answer the questions based on it. You may refer to this material as often as you wish.

By Executive Order dated September 8, 1939, the Executive Office of the President was organized. Among the divisions of the Office provided for in the Order were the White House office, the Bureau of the Budget, and "in the event of a national emergency, or threat of a national emergency, such office for emergency management as the President shall determine." The Bureau of the Budget had theretofore been "transferred from the Treasury Department to the Executive Office of the President," to use the words of Reorganization Plan No. I which was submitted to Congress on April 25, I939, by the President and which became effective on July I, I939. Reorganization Plan No. I2 did not make any mention for an "office for emergency management" or of The White House Office, but no question is raised as to the statutory or constitutional authority of the President to set them up.

By Administrative Order dated May 25, I940, the Office for Emergency Management was created and by Executive Order dated April II, I94I, the Office of Price Administration was set up as a division of the Office for Emergency Management.

The Independent Office Appropriation Act, approved April 5, I94r, made appropriations for, inter alia, The White House Office and the Bureau of the Budget--both 
under the general heading, in the enrolled copy of the Act, "Executive Office of the President." In addition, under the general heading "Emergency Funds for the President," it appropriated money "To enable the President, through appropriate agencies of the Government, to provide for emergencies affecting the national security and defense.... without regard to the provisions of law regulating the expenditures of Government funds or the employment of persons in the Government service, such as .... the civil service ... . laws. ...."

The Second Deficiency Appropriation Act, I94I, approved July 3, x94I, made appropriations under the general heading "Executive Office of the President" for inter alia, the Bureau of the Budget and "The Office for Emergency Management, established in the Executive Office of the President by administrative orders . . . . and subordinate or related bodies in the work of national defense. ...." Unless otherwise stated, it is to be assumed hereafter that the Office of Price Administration gets its funds from this source.

Section 9 of the Hatch Act, approved August 2, I939, provides that "No officer or employee in the executive branch of the Federal Government, or any agency or department thereof, shall take any active part in political management or in political campaigns." Exempt from the provisions of Section 9 are "( $\mathrm{I})$ the President or Vice President of the United States; (2) persons whose compensation is paid from the appropriation for the office of the President; (3) heads and assistant heads of executive departments; (4) officers who are appointed by the President, by and with consent of the Senate, and who determine policies to be pursued by the United States in its relation with foreign powers or in the Nation-wide administration of Federal laws."

Another section ( $9 \mathrm{~A})$ of the Hatch Act provides that "It shall be unlawful for any person employed in any capacity by any agency of the Federal Government, whose compensation.... is paid from funds authorized or appropriated by any Act of Congress, to have membership in any political party or organization which advocates the overthrow of our constitutional forms of government in the United States."

Rule I of the Civil Service Commission, issued under appropriate statutory authority, provides that "Persons who .... are in the competitive classified service.... shall take no part in political management or political campaigns." It was first adopted by Executive Order in 1907 and has been applied continually since then.

Section I2 of the Hatch Act, added by an amendment approved July I9, I940, extends substantially the same restrictions on political activity contained in Section 9 to any "... officer or employee of any State or local agency whose principal employment is in connection with any activity which is financed in whole or in part by loans or grants made by the United States or by any Federal agency. . . . " Certain exceptions were made upon which no questions are based.

Questions 20-27 are based on the foregoing material and are to be answered on the basis of this material alone. Disregard later enactments such as the Emergency Price Control Act of 1942 .

20. Which ons of the following considerations is entitled to the greatest weight in determining whether the expression "Office of the President" as used in the second exception of Section 9 of the Hatch Act includes the Office of Price Administration? (A) The fact that Section 9 applies only to the executive branch of the Government (B) the fact that most of the employees of the Office of Price Administration would be barred from political activity under Civil Service Rule I, even if not included within 
the Hatch Act (c) the transfer of the Bureau of the Budget from the Treasury Department to the Executive Office of the President (D) the nature of the other three exceptions to Section 9 (E) the lack of exceptions to the section forbidding membership in subversive organizations.

2I. Which one of the following considerations tends most strongly to supporT the view that the gresat mass of ordinary employees of the Office of Price Administration are subject to Section 9 of the Hatch Act? (A) About a year after the Hatch Act was originally enacted, Congress amended it to include certain State employees engaged in activities financed in whole or part by Federal funds. No other significant changes were made in the Act (B) most of the employees of the Office of Price Administration are barred from political activity under Civil Service Rule I (c) in March, 1939, when the drafts of the Act were being considered in Congress, the Office of the President consisted of little more than the President's immediate entourage (D) The Office of Price Administration is a part of the Office for Emergency Management $(E)$ The Office of Price Administration was not mentioned by name in any appropriation act.

22. Which one of the considerations listed in question 35 above, tends most strongly to OPPOSE the view that the great mass of ordinary employees of the Office of Price Administration are subject to Section 9 of the Hatch Act?

23. An inquiry is made whether a rural mail carrier may seek the elective office of Chief of the Volunteer Fire Department of a village without violating the Hatch Act. The contest has none of the characteristics of a regular political campaign and party lines are not drawn. Which one of the following is the principal question of construction to be settled in answering this inquiry? The question is whether (A) a rural mail carrier is in the competitive classified service governed by Rule I of the Civil Service Commission (B) he is actively engaged in political management if his campaign is managed by someone other than himself (c) the inquirer's service as a rural mail carrier constitutes his principal employment (D) the Volunteer Fire Department receives any direct or indirect assistance through Federal grants (E) seeking such an elective office constitutes taking an active part in political campaigns.

24. An inquiry is made whether an employee of a Conservancy District may seek election to the Senate of his State without violating the Hatch Act. The Conservancy District is in the form of an authority established by the State. Its capital was obtained by the sale of bonds, some of which have been purchased by the Reconstruction Finance Corporation. Which one of the following is the principal question of construction to be settled in answering this inquiry? The question is whether $(A)$ the $\operatorname{Re}$ construction Finance Corporation bought more than half of the bonds (B) the Conservancy District was established before or after the effective date of Section I 2 of the Hatch Act (c) the activities of the Conservancy District are financed in part by funds made available by a Federal agency (D) the candidate is campaigning as the candidate of a political party or as an independent ( $E$ ) the Conservancy District is a Federal agency.

25. An inquiry is made whether a substitute railway postal clerk may serve as secretary of a major political party, receiving payment from party funds, when not engaged in postal work without violating the Hatch Act. Which one of the following 
is the principal question of construction to be settled in answering this inquiry? The question is whether (A) the party's activities concerned Federal offices or were limited to campaigns for State and local offices (B) Civil Service Rule I is applicable to this clerk (C) a person employed on a part-time basis is subject to the restriction on political activities during periods when he is not employed (D) the railroad is interstate or intrastate $(E)$ local branches of political parties are included within the meaning of the term "local agency."

26. Which one of the following-described persons is most clearly within the scope of Rule I of the Civil Service Commission? (A) A county jailer of State X. He derives part of his compensation directly from the United States Government on a contractual basis for keeping and feeding Federal prisoners (B) a junior accountant in the competitive classified civil service in the Bureau of the Budget (C) an expert on textile products in the Office of Price Administration. He is a non-civil service employee, although for purposes of fixing his salary his job has been classified by the Civil Service Commission (D) a non-civil service clerk-typist in the White House office (E) a research chemist in the Experiment Station of the College of Agriculture of X State University. He was appointed through the civil service procedure of State $X$. The functions of the EXperiment Station are financed in part by grants made by the United States.

27. As far as the laws given herewith are concerned, which one of the followingdescribed persons could most clearly lawfully have membership in a political party advocating the overthrow of the constitutional government of the United States? (A) An assistant head of one of the executive departments of the United States Government (B) an executive officer of a State agency engaged in distributing funds appropriated by Congress for relief purposes (c) an officer of the United States Government appointed by the President by and with the consent of the Senate, but who has no policy-forming functions (D) any employee of the Federal Government provided he takes no active part in political management or in political campaigns (E) any noncivil service employee of the Federal Government.

\section{Questions 28-31}

28. Assume that you have been charged with the drafting of a Civil Aeronautics Act. It is desired to include in the Act a provision which will require that 75 per cent of the interest in all air carriers be owned and controlled by American citizens. Which of the following proposed statutory drafts most effectively accomplishes this objective? (None of the alternatives is necessarily perfect; choose the ONE which most exactly accomplishes the objective stated.)

(A) No air line may'operate within the United States unless at least 75 per cent of its outstanding stock is registered in the names of citizens of the United States.

(B) No air line may operate in the United States if more than 25 per cent of its stock is owned or controlled by persons not citizens of the United States or held for the benefit of such persons.

(c) No air line may operate in the United States unless at least 75 per cent of its stock is bona fide owned by American citizens.

(D) The common stock of any air carrier must be predominantly owned and controlled, to the extent of 75 per cent at least of its total par value, by citizens of the United States. 
(E) After the date of the passage of this Act, not more than 25 per cent of the stock in any air line may be sold to any person or persons not citizens of the United States.

29. Occasionally some of the stock of an air line is owned by a corporation. Assuming that it is not desirable to prohibit foreign stock interests entirely, which oNE of the following proposed statutory provisions in relation to corporate ownership of air-line stock would best effectuate the basic aim that air lines should, to the extent of 75 per cent, be owned and controlled by American citizens? A corporation owning stock in an air carrier is to be considered an American citizen if 75 per cent of its stock is owned and controlled by American citizens.

(A) None except American corporations may own or hold a beneficial interest in air-line stock; and it shall be assumed that a corporation owning air-line stock is a foreign corporation if more than 25 per cent of its outstanding stock is foreign owned.

(B) When a corporate owner is included among those holders of 75 per cent of the stock of an air line whom the carrier denominates to comply with the citizenship requirement of the Act, the carrier shall prove that the holders of at least 75 per cent of the shares of such corporate owner's outstanding stock are American citizens, and it shall make proof of the citizenship of the corporate shareholders in the same manner as for its own shareholders.

(c) Any corporation owning air-line stock is subject to the same citizenship requirements as is the air carrier corporation itself and is subject to the same requirements that it prove the citizenship of its shareholders.

(D) No corporation or other holding company may own more than 25 per cent of the stock in any air carrier; and any such holding company which at the present time shall own an excess of the allowed amount of stock must divest itself of such ownership within 5 years of the date of the passage of this Act.

(E) No foreign corporation may own, control, or have a beneficial interest in móre than 25 per cent of the stock of any air line.

30. Assume that a Civil Aeronautics Act has been adopted and that you are instructed to draft a regulation under the Act which will establish a standard by which air lines shall prove citizenship of the holders of 75 per cent of the stock interest. Assume that all air carriers are corporations, some of which have as few as 5 to 40 stockholders while others have as many as 20,000 . The maximum absolute proof of citizenship is desired, but no carrier can reasonably be expected to prove absolutely the citizenship of thousands of persons. You are, therefore, to work out a regulation which will provide the maximum practical assurance of citizenship. You may assume that a presumption of citizenship from residence, with proper safeguards, is an acceptable device. Which oNE of the following would you select?

(A) If 90 per cent of the shareholders are recorded in the books of the carrier as having American residences, it is to be presumed that 75 per cent of the whole number are American citizens.

(B) Corporations with a small number of shareholders shall prove citizenship of every individual. Corporations with a large number shall prove citizenship of 75 per cent of their shareholders by showing that each holder of 2 per cent or more of stock is an American citizen and that the holders of 90 per cent of the shares are residents of the United States.

(c) Corporations having 40 shareholders or less shall prove citizenship of 75 per 
cent of the shareholders individually. Corporations having more than 40 shareholders shall prove citizenship by showing that 90 per cent of the shareholders are residents of the United States.

(D) Corporations having 40 shareholders or less shall prove the citizenship of the holders of 75 per cent of the outstanding stock of the corporation; corporations having more than 40 shareholders shall prove citizenship by showing that each holder of 2 per cent or more of the stock is an American citizen and that 90 per cent of the total outstanding stock is held by American residents.

(E) Every transfer of air-line stock must be recorded in the books of the carrier along with a sworn statement that the purchaser of the stock is a resident of the United States, or, where such a statement is not practically available, a statement by a representative of the aforementioned purchaser.

3I. Assume that the Civil Aeronautics Act further requires that two-thirds of the directors of each air line shall be citizens of the United States. You are to draft a regulation establishing the most effective and practicable procedure for proving such citizenship. Assume that birth certificates, family Bible entries, and passports issued by the State Department are some possible means of proving citizenship. No air line has so large a number of directors that mere number alone prevents the use of any test of citizenship, and the standard used, therefore, may be as rigorous as seems desirable. Which oNE of the following would you select?

(A) Each carrier shall meet the citizenship requirement of the Act in respect to its directors by causing two-thirds of the members of the Board of Directors to file with the Secretary of the Civil Aeronautics Board sworn affidavits that they were born in the United States. The Secretary shall determine in each case whether the proof made is adequate and his decision may be appealed to the Board.

(B) Each air line shall file with the secretary of the Civil Aeronautics Board evidence of citizenship of two-thirds of the members of its Board of Directors. Such evidence shall consist in each case of either a birth certificate, a certified copy of a family Bible entry, or a passport.

(c) Each air line shall file with the Secretary of the Civil Aeronautics Board birth certificates, certified copies of family Bible entries, or other evidences of American citizenship of two-thirds of the members of its Board of Directors. The Secretary shall determine in each case whether the proof made is adequate and his decision may be appealed to the Board.

(D) Each of the directors of an air line making up two-thirds of the total Board of Directors of said air line shall file the best possible proof of citizenship with the Civil Aeronautics Board. No substitutes for the best proof shall be accepted by the said Board.

(E) In every case brought before the Civil Aeronautics Board, each member of the Board of Directors of the carrier bringing a case shall appear with his evidence of citizenship and be available for cross examination by Board Counsel on the question of his citizenship.

Analogies form.-This form of question calls for the discovery of a relationship between two things or ideas. It is in form a variation of the multiple-choice type. It has been used rather widely in intelligence test- 
ing. When used in an achievement test, such as a test of legal qualifications, it tends to appear artificial in content and to savor a bit of mere puzzle-solving and therefore may annoy persons expecting a "practical" examination. It was used experimentally in the attorney examination to the extent of ten questions, of which two examples are given below. Statistical analyses of the scores, as subsequently made, showed that these were good questions: they had high discriminating power and the scores correlated very highly with scores on the examination as a whole.

\section{Questions 32-33}

\section{ANALOGIES FORM}

In each of the questions following, select the oNe word of the five lettered choices (A to $\mathrm{E}$ ) which most closely expresses the relationship called for and blacken the space on the answer sheet bearing the same letter as the word selected.

32. DONOR is to VENDOR as GIFT is to (A) vendee (B) donee (C) chattel (D) sale (E) barter.'

33. OWNER is to BAILEE as TITLE is to (A) bailor (B) possession (C) recording (D) deed (E) property.

Matching form.-A relatively simple type of question is the matching type, in which items listed in one column are to be matched with related items in a. second column-for example, a list of authors to be matched with a list of book titles. This type is useful to test information, for it covers a great deal of material in a short space. It is not very useful for testing any considerable amount of thought or reasoning. The attorney examination included only twenty questions of this type, of which five are reprinted below.

\section{MATCHING FORM}

In items 34 through 38 , by marking the proper spaces on the Answer Sheet, associate each act listed in Column I with its related subject in Column II.

\section{Column I}

34. Norris-LaGuardia Act

35. Glass-Steagall Act

36. Robinson-Patman Act

37. Frazier-Lemke Act

38. Hatch Act

\section{Column II}
A. political activity
B. price discrimination
C. injunctions
D. banking practices
E. bankruptcy

Master list.-A type of question of which considerable use was made is that which is sometimes called the master list form, in which, instead of having a separate group of alternative answers for each item, a number of questions are to be answered on the basis of the same group of alternatives. It is a useful form for testing ability to classify data and to recognize similarities, contrasts, consequences, and implications. 


\section{MASTER IIST FORM}

\section{A. GENERAL INFORMATION}

In EACH of the questions 39 through 42 , indicate the tax to which the statement made most clearly applies. Use the following code:
(A) poll tax
(B) property tax on tangible personalty
(C) income tax
(D) property tax on intangible personalty
(E) import duties

39. The burden of the tax is most likely to be shifted by the person who first pays the tax.

40. The burden of the tax is least likely to be shifted by the person who first pays the tax.

4I. The amount levied on the individual is generally most likely to vary with his ability to pay.

42. The amount levied on the individual is generally least likely to vary with his ability to pay.

\section{Questions 43-49}

\section{B. IEGAL}

Read the summaries of the decisions in the four cases $(A-D)$ below, and then apply the principles involved in answering the questions $43-49$ which follow.

A. Rexford v. Trent held that a State may prohibit the manufacture of a product regarded in its general policy to be deleterious even though the manufacturer intends to ship it to customers in another State. An article does not become an object in interstate commerce merely by reason of the fact that it is manufactured with the intention to ship it to another State.

B. Tipton v. Rio Grande R. Co. held that the liability of interstate railroad carriers to make compensation for personal injury suffered by their employees engaged in interstate commerce was regulated exclusively and inclusively by the Federal Employers Liability Act, and Congress having thus fully covered the subject, there was no room for State regulation of personal injuries to such employees by workmen's compensation laws.

c. Kidd v. Dalbey held unconstitutional a State statute requiring a license from all persons peddling goods not produced or manufactured within the State. No such license was required for peddling domestic goods. The act was held to be a discrimination burdening interstate commerce.

D. In Crenshaw v. Lipscomb, a house-to-house brush salesman was charged with violation of a statute of State A requiring a license to engage in peddling or soliciting. The defendant did not sell any brushes from his samples, but merely took orders for goods which were then sent to the customer direct from the company's factory located in State B. It was held that the statute was an invalid attempt to regulate or burden interstate commerce.

In each of the following questions $(43-49)$ determine which one of the four cases above is most applicable as a precedent. 
43. The question arises whether a State occupation tax imposed on all mining done in the State might validly be assessed against a company operating an open pit mine in the State, where the ore is severed from the bed by machinery and lifted directly into waiting railroad cars which then transport it to the company's customers in other States. The company sells no coal within the State.

44. A person was charged with violating a State statute requiring that cattle brought into the State for dairy or breeding purposes should be certified to be free from Bang's Disease by the chief cattle officer of the State of origin. The Federal Cattle Contagious Disease Act authorized the Secretary of Agriculture to establish regulations concerning interstate transportation from any place where he had reason to believe that animal diseases existed, and provided that when an inspector of the Bureau of Animal Industry certified that he had inspected cattle and had found them to be free from communicable disease, they should be permitted to be transported "without further inspection or the exaction of fees of any kind, except such as may at any time be ordered or exacted by the Secretary of Agriculture." Defendant's cattle had been inspected by the Bureau of Animal Industry but not by officials of the State of origin.

45. A company making electrical devices, 90 per cent of whose products are sold and shipped in interstate commerce, was charged with violation of a State statute forbidding the employment of any person for more than 8 hours per day in any mill or factory. There was no Federal regulation on the subject at the time.

46. A State statute provided for the inspection of all grain brought in from other States, and for an inspection fee of 15 cents per roo pounds- 60 times the actual cost of inspection.

47. A wholesale grocery house is located in State A, near the State line. It receives telephone or mail orders from retailers, some of whom are across the State line, in State B. The company fills such orders by delivery of the goods in its own trucks. The question is whether the company may constitutionally be required to pay an occupation tax levied in State B upon all wholesale dealers.

48. An international bridge over a river between State $A$ and Canada is built by a private corporation under express authority of an act of Congress. The State of A now wishes to compel the company to add a footpath to the bridge.

49. A certain cotton compress and warehouse company challenged the validity of a State license tax upon the privilege of operating a cotton compress and a tax upon each person operating a warehouse, the taxes being graduated according to the number of bales of cotton compressed and according to the storage capacity of the warehouse. The bulk of the company's cotton was ultimately shipped to points outside the State. The company alleged that the tax was a burden on interstate commerce.

As already. said, the examination consisted of eighty legal questions, eighty verbal and ninety on general information. One of the general information questions was not counted because it was subsequently found to be defective. The legal questions, because they were more difficult and 
required much more time, were weighted three points each, as against one point for each of the non-legal questions. A perfect score under this method was 409 .

After the examination papers had been scored, certain statistical studies were made of the results. ${ }^{3}$ A group of 500 papers was selected from the total of 13,29 I, in such a way as roughly to constitute a geographically representative sample. From this sample, a subsample of 200 was selected. ${ }^{4}$ Using the subsample of 200 , the scores on the several parts of the examination were analyzed. Table I summarizes the results.

The mean scores show that the three parts of the examination proved to be of almost equal difficulty to the competitors. We had expected the legal questions to be rather more difficult than the others. The results perhaps indicate that many of the competitors were fairly good legal technicians, but were relatively weak in educational and cultural background.

The degree of difficulty proved to be exactly as desired. Ideally, an examination should aim to be of such difficulty for the group taking it that the scores will range from a little above zero to a little below perfect, with

3 Mr. Frederic M. Lord of the Test Construction and Review Unit, U.S. Civil Service Commission, conducted the statistical studies. The writer is indebted to Mr. Lord not only for the compilation of the statistics but also for his collaboration in writing the part of this article which discusses these statistics.

4 The 500 papers were arranged in serial order according to their examination numbers, and the second paper, the fifth, the seventh, the tenth, the twelfth, etc., were drawn out so as to provide a subsample of 200 . A comparison was then made of the mean or average score and the standard deviation on the total, the sample and the subsample. The figures obtained were as follows:

\begin{tabular}{l|c|c|c}
\hline \hline & $\begin{array}{c}\text { Y3,29r } \\
\text { Competitors }\end{array}$ & $\begin{array}{r}\text { Sample of } \\
500 \\
\text { Competitors }\end{array}$ & $\begin{array}{c}\text { Subsample } \\
\text { of 200 } \\
\text { Competitors }\end{array}$ \\
\hline Mean.............. & $\begin{array}{r}249.8 \\
54.5\end{array}$ & $\begin{array}{r}247.5 \\
55.0\end{array}$ & $\begin{array}{r}243.7 \\
5 I .8\end{array}$ \\
\hline
\end{tabular}

A difference as large as the obtained difference between the mean of the sample of 500 and the mean of the total group could be expected to occur by chance about once in three times. A difference as large as that between the mean of the sample of 200 and that of the total group could be expected to occur by chance about once in nine times. In the case of the sample of 500 papers the difference is not much larger than would be expected to occur by chance; in the case of the subsample of 200 papers, the difference is considerably larger than would be expected, but it does not appear to be large enough seriously to impair the practical usefulness of the subsample.

A discrepancy as large as the obtained discrepancy between the standard deviation of the sample of 500 papers and the standard deviation of the total group would occur by chance about three times out of every four; a discrepancy as large as that between the standard deviation of the sample of 200 papers and the standard deviation of the total group would occur by chance about once in three times. Hence these discrepancies are approximately what would be expected to occur by chance, and both the samples may be considered to be representative of the total group in this respect. 
the concentration of grades around the middle. (The usual aim of teachers to have 80 to 90 per cent of all scores fall above some arbitrary "passing grade" is not considered by test construction experts to be good practice.) The scores on the attorney examination ranged from 35 to 386 out of a

TABLE 1

STATISTICS ON SUB-TESTS AND TOTAL EXAMINATION FROM SAMPLE OF 200 PAPERS

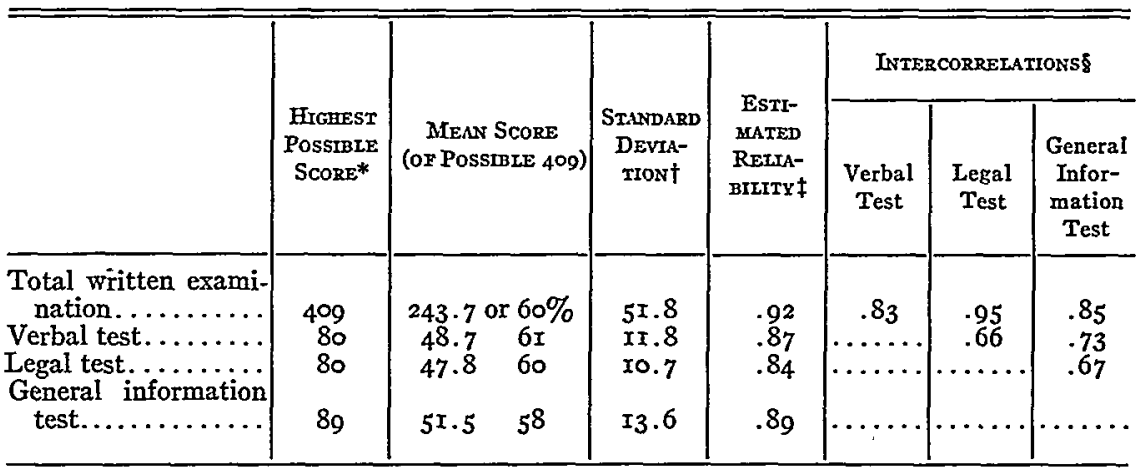

* The score of a competitor on any of thè sub-tests is the number of items answered correctly; in the tota score, the legal questions were weighted three for one.

tThe standard deviation is a measure of the spread or scatter of the scores around their average. It is obtained by squaring each deviation, i.e., the amount by which each score varies from the average, adding the squares all together, dividing by the total number of scores and taking the square root. (Squaring all the deviations may at first sight seem unnecessary, but it must be remembered that, without squaring, the sum of the deviations from the mean would necessarily be zero. Squaring is the simplest process for obtaining a quantity varying with the dispersion and treating the deviations as if they were all of the same sign.) The size of the standard deviation is such that, in a normal distribution, about $68 \%$ of all the scores are within one standard deviation of the mean; thus, in the subsample of 200 , probably about $68 \%$ of all the scores lay within the range of 51.8 points above and below 243.7. A range of six times the standard deviation usually includes $99 \%$ or more of all the cases in a normal distribution.

$f$ "Reliability" is a term used technically to mean the degree to which a test is consistent in measuring whatever it measures. This consistency is never perfect. If the very same test is given twice to the same group of subjects, the second set of scores will vary from the first. The variance will be even greater if a somewhat different, though purportedly similar, test is given. The correlation between two equivalent forms of the same test is called a "reliability coeficient." This coefficient may range from zero to near perfection or I.00. It is usually considered desirable that the reliability of a total examination should be at least .oo for the purpose of individual measurement. The reliability of the entire attorney examination is shown in Table I to be .92 , and this may be considered as satisfactory. The reliability coefficients shown were estimated by the Kuder-Richardson formula, case IV. Kuder and Richardson, The Theory of the Estimation of Test Reliability, Psychometrica, Vol. 2, No. 3, pp. I5I-I60.

8 The figures shown under this heading are the "coefficients of correlation" between two parts of the examination. A coefficient of 1.00 shows perfect positive or direct relationship. Thus a correlation of $x .00$ between the legal and verbal parts would mean that the examinee having the highest score on the legal part would also be highest on the verbal, the second highest on the legal would also be second on the verbal, and so on down to the last one. A coefficient of .00 means that there was no correlation between the two sets of papers greater than was to be expected by mere chance. A coefficient of $-x$.oo indicates a relationship which is perfect but negative or inverse -i.e., the highest paper on one part would be lowest on the other, etc.

possible 409 , with a mean score of 249.8 (6r per cent), and a standard deviation of $54.5 .{ }^{5}$ A mean of $6 \mathrm{r}$ per cent sounds higher than it really is. On an objective type examination, a competitor can obviously obtain a certain number of correct answers by mere chance. On this examination, the average score likely to be obtained by chance alone was 90 , or 23 per cent. If this mere chance score were taken as zero, and the actual score figured from that as zero point, it will be seen that the mean score of the

5 See note 4 . 
examinees was just about $5 \circ$ per cent of the difference between chance and perfect (the median point between 90 and $409=249.5$ ). This is probably the optimum from the point of view of validity.

The statistics raise a question whether weighting the legal questions more than the non-legal served any significant purpose. If the three parts of the examination were weighted equally in the scoring, the estimated reliability of the total examination would be .95, as compared to the value of .92 obtained when the legal test is given a weight of 3 . The correlation between the total examination scores obtained by the two methods of weighting would be .98 , indicating that the two methods of weighting will yield very similar results.

This is not surprising. Educational test experts have shown that weighting questions or parts of an examination frequently has less effect on scores than it is intended to have. On the attorney examination, it was felt that the total score should reflect mainly the score on the legal questions; that while the other material was relevant in testing legal capacity, it should not outweigh the strictly legal. As it turned out, there was a rather high correlation between the three parts, i.e., those who did well on any one part tended to do well on the others. The high degree of correlation indicates that the three parts to a large extent tested the same abilities, and were, to that extent, redundant.

It was realized, of course, that the several parts did to a certain extent cover similar ground. Thus the reading comprehension questions on the verbal part called for essentially the same capacities as the legal questions on statutory construction. (Compare, for example, questions I and 2 with questions I6-I9, above.) The part on general information included a number of questions calling for legal information (legal bibliography, recognition of important legal book titles, legal personages, etc.). A high correlation was therefore to be expected.

In order to see how the results on the examination agreed with other criteria of legal ability, the competitors in the sample of 500 were divided into three groups; the first, an "honors" group, i.e., those whose records in law school had been high enough for them to achieve membership on the board of editors of a law review or membership in the Order of the Coif; the second, an "average" group, made up of those who had not achieved such honors but who had not fallen into the third group; and the third, those who had failed a bar examination. It is realized that the criterion for each of these groups is probably imperfect, and, moreover, that there are law schools having neither a law review nor a chapter of the Order of the Coif. However, no other objective criteria were available. Standing 
in law class (e.g., the top ro per cent) could not be used because too many schools do not announce or keep records of such ranking, and the applicant's own estimate of his rank would probably not be reliable. The results, given in Table 2, show a gratifying measure of agreement between the judgments of law school professors and bar examiners and the results obtained by the examination.

A difference as large as the difference between the mean scores of the first and the third groups in the preceding table could occur by chance only about once in a thousand times; a difference as large as the difference between the mean scores of the second and third groups could occur by chance only about once in fifty times. It is therefore probably safe to con-

TABLE 2

TOTAL SCORE OF CERTAIN GROUPS OF COMPETITORS FROM SAMPLE OF 500 PAPERS*

\begin{tabular}{|c|c|c|c|c|}
\hline & Number & $\begin{array}{l}\text { Per Cent } \\
\text { of Group }\end{array}$ & $\begin{array}{l}\text { Mean } \\
\text { Score }\end{array}$ & $\begin{array}{l}\text { Standard } \\
\text { Deviation }\end{array}$ \\
\hline 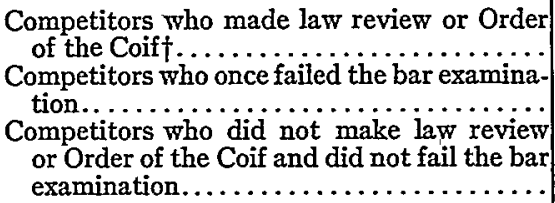 & III & $\begin{array}{r}3 \\
22\end{array}$ & $\begin{array}{l}288.6 \\
237.5\end{array}$ & $\begin{array}{l}32.7 \\
49.2\end{array}$ \\
\hline
\end{tabular}

* Fifty-five competitors, or in per cent, are omitted because of doubt as to how they should be classified.

$\dagger$ One competitor who made law review and who also failed in the bar examination is included in this group rather than in the succeeding group.

sider these differences as significant and as not attributable to chance fluctuations.

In order to test further the correlation between examination scores and bar examination results, the bar examination records of 125 New York competitors who were successful on the examination were obtained from the New York State Board of Bar Examiners. The New York board keeps records of competitors' standings by percentiles. Percentiles are recorded separately for the substantive and the adjective parts into which the New York examination is divided. Although approximately $5^{\circ}$ per cent of those taking bar examinations fail, it is noteworthy that of these I25 eligibles on the attorney register, only I 2 had failed to pass both parts of the New York bar examination on their first attempt. Moreover, the II3 who passed had stood relatively high. Of the II3, 44 were within the top ten percentiles on the adjective part, and 42 were within the top ten percentiles on the substantive. Another 2I were within the next ten 
percentiles on the adjective and 27 on the substantive. In other words, more than half of the New York candidates who were placed on the attorney register had stood within the top one-fifth on the New York bar examination.

In June, I943, the same attorney examination, using the same questions, was offered to certain limited groups of applicants, including current law school graduates. While law school grades vary widely from school to school, yet for members of the same class in the same school, class ranking is a very reliable index of relative competence. A search was made for cases where several members of the same I943 law school class had taken the attorney examination. Sixty-six individuals, from 16 different schools, were found. The rankings in law school and on the examination were remarkably similar. Of one western state university law class of ten members, six took the examination. The comparative rankings are typical of results found in other schools:
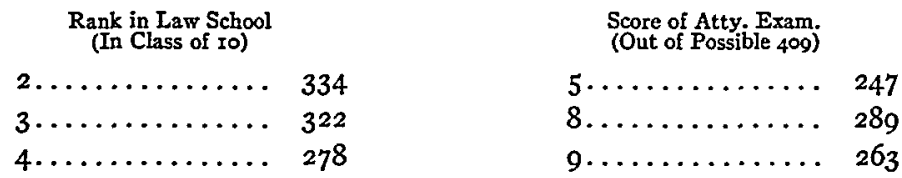

Rank in law school was taken from the applicant's own statement. We know that students do not always have exact information regarding class rank, and may give themselves the benefit of a doubt. Exact school records might reveal an even higher degree of correlation between law school records and attorney examination scores than the available data indicated.

An item analysis was made to determine the difficulty of each question on the examination and the correlation of the score on each question with the total score on the particular part of the test in which the question belonged. The analysis was based on a subsample of 200 papers chosen by the same method as that used to select the subsample previously discussed. The results are summarized in Tables 3 and 4 .

"Tetrachoric correlations" were obtained by a formula ${ }^{6}$ based on a division of the 200 sample papers into the roo with higher scores and the roo with lower, on the subtest of which the question was a part, and a further division of these two groups into those who were correct and those who were wrong in their answers to the specific question (hence "tetrachoric" or fourfold). The coefficient of correlation obtained represents the

6 For a description of the formula, see Statistical Procedures and Their Mathematical Bases, by Peters and Van Voorhis, at p. 366 (r940). 
TABLE 3

ITEM ANALYSIS RESULTS: FREQUENCY DISTRIBUTION OF PER CENT OF CANDIDATES ANSWERING ITEMS CORRECTLY

\begin{tabular}{|c|c|c|c|}
\hline \multirow[b]{2}{*}{$\begin{array}{c}\text { Per Cent of CandDates } \\
\text { Answerng Correctiy }\end{array}$} & \multicolumn{3}{|c|}{ Nusraer of Itrexs } \\
\hline & $\begin{array}{c}\text { Verbal } \\
\text { Test }\end{array}$ & $\begin{array}{l}\text { Legal } \\
\text { Test }\end{array}$ & $\begin{array}{c}\text { General } \\
\text { Information } \\
\text { Test }\end{array}$ \\
\hline 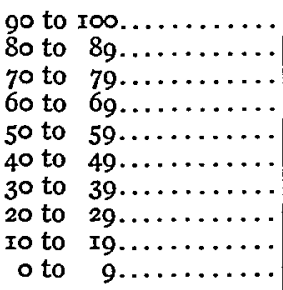 & $\begin{array}{r}8 \\
\text { I3 } \\
\text { I3 } \\
\text { I3 } \\
\text { II } \\
4 \\
8 \\
7 \\
3 \\
0\end{array}$ & $\begin{array}{r}4 \\
9 \\
22 \\
8 \\
x 6 \\
9 \\
6 \\
4 \\
2 \\
0\end{array}$ & $\begin{array}{r}5 \\
7 \\
20 \\
14 \\
\text { I } \\
\text { I5 } \\
6 \\
9 \\
1 \\
0\end{array}$ \\
\hline $\begin{array}{l}\text { Total............ } \\
\text { Median........ }\end{array}$ & $\begin{array}{r}80 \\
.68\end{array}$ & $\begin{array}{l}80 \\
.63\end{array}$ & $\begin{array}{r}89 \\
.60\end{array}$ \\
\hline
\end{tabular}

TABLE 4

ITEM ANALysis ResUlts: FrequenCy DISTRIBUTION OF TETRACHORIC ITEM-TEST CORRELATIONS

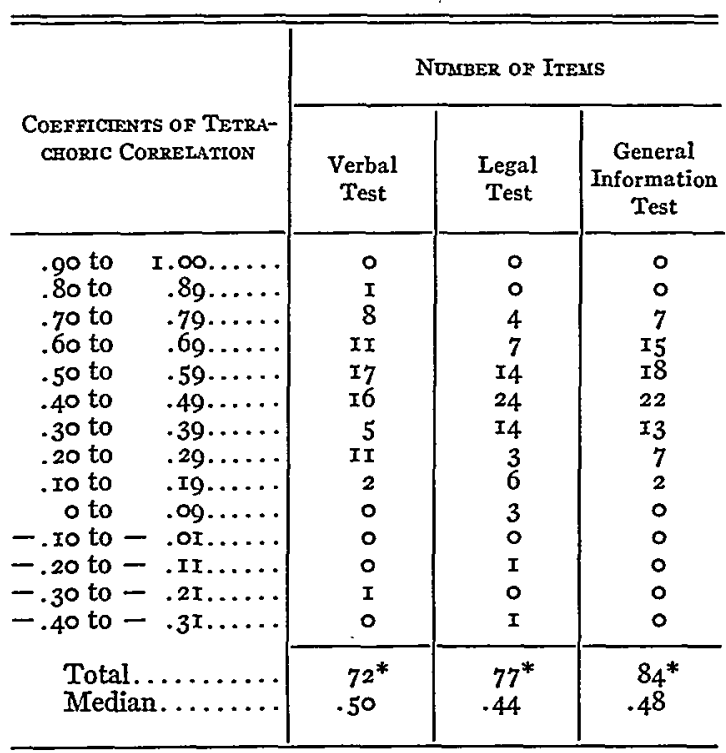

* Tetrachoric correlations have not been calculated for items answered correctly by more than 90 or by less than ro per cent of the competitors, since correlations calculated for such items are too much affected by small chance fluctuations in the data. 
degree of agreement between the result on the individual item with the total score on that part of the examination.

Anyone who has attempted to draft objective questions appreciates how difficult it is to frame questions which are unambiguous and free from the possibility of a reasonable interpretation leading to a conclusion different from that intended by the draftsman. All the questions in the federal examination were pretested repeatedly by submitting them to numerous attorneys in the government. Those found open to rational misinterpreta-

TABLE 5

AVERAGE WRITTEN TEST SCORES OF EXAMINEES RATED BY ORAL EXAMINING COMMITTEES

\begin{tabular}{|c|c|c|c|c|c|}
\hline \multirow{2}{*}{ State } & \multicolumn{5}{|c|}{ Rating } \\
\hline & $\begin{array}{l}\text { Outstand- } \\
\text { ing }\end{array}$ & Excellent & Good & Fair & Ineligible \\
\hline 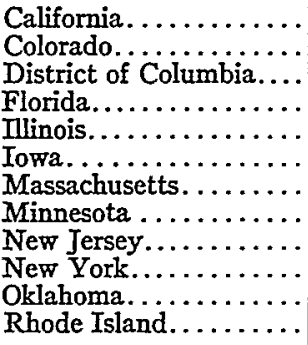 & 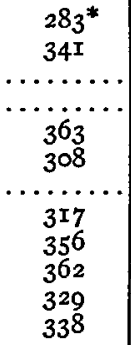 & $\begin{array}{l}335 \\
32 I \\
322 \\
325 \\
330 \\
3 I I \\
337 \\
327 \\
332 \\
348 \\
33 I \\
309\end{array}$ & $\begin{array}{l}316 \\
303 \\
321 \\
309 \\
316 \\
304 \\
317 \\
302 \\
317 \\
346 \\
299 \\
\ldots\end{array}$ & 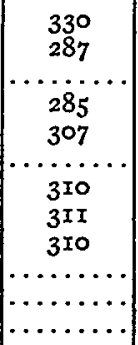 & $\begin{array}{l}303 \\
309 \\
295 \\
284 \\
303 \\
291 \\
3 I 5 \\
302 \\
3 I 5 \\
339 \\
294 \\
280\end{array}$ \\
\hline
\end{tabular}

* Represents one case. The California committee stated its belief that the low score on the written test in this case was caused by illness resulting in an operation shortly after the written examination.

tion were eliminated or rewritten and tested again, until all were apparently air-tight. This process of drafting, testing, and redrafting lasted almost nine months. It had as its reward a remarkably small number of questions which on item analysis proved not to operate correctly. The summary in Table 4 shows only three items out of the total of 249 in which the correlations were negative, i.e., in which competitors whose total scores on the subtest in which the question appeared were low did better than those whose total scores were high. Any item on which the generally poorer competitors do better than those whose totals are high can be considered defective, but the presence of three such items is not sufficient materially to affect the scores.

After the oral examinations had been held, the scores on the written test were compared with the judgments of the oral examining committees. 
The committees had been asked not only to determine whether a candidate was eligible or ineligible for inclusion on the register, but also to rate each candidate as "outstanding," "excellent," "good," "fair," or "poor," on the basis of his score on the written test, his past training and experience and the impression he made on oral interview (manner, oral expression, legal reasoning, logical organization, and effectiveness of arguments, etc.).

Table 5, giving the average scores on the written test for the group achieving each grade on the oral examination in eleven states, shows that those attaining the highest scores on the written test tended to make the best impression on the oral committees. The eleven states listed were selected because they were the only states in which there were a sufficient number of applicants who achieved satisfactory scores on the written test to permit sending to oral examination twice the number ultimately to be selected for the register. The same tendency, however, appeared in other states.

\section{CONCLUSION}

The written attorney examination was an experiment both in its substantive composition and in the form of questions used. Statistical analyses tend to establish the validity and reliability of the examination. Thus, there is a definite correlation between scores on the examination and other criteria such as law school and bar examination records. An equally clear correlation appears between written test scores and the judgments of the state oral examining committees. It may fairly be said, therefore, that although the written attorney examination did not attempt to test for knowledge of law at all, its results are supported not only by the results shown on such criteria of legal knowledge as law school and bar examinations, but also by the judgments of experience, personality and proficiency arising from the oral examination. 